\title{
Application of Umbilical Cord Blood Stem Cells in Regenerative Medicine
}

\author{
Anna Meiliana ${ }^{1,2, *}$, Andi Wijaya ${ }^{2,3}$ \\ ${ }^{1}$ Postgraduate Program in Clinical Pharmacy, Padjadjaran University, Jl. Eijkman No.38, Bandung, Indonesia \\ ${ }^{2}$ Prodia Clinical Laboratory, Jl. Cisangkuy No.2, Bandung, Indonesia \\ ${ }^{3}$ Postgraduate Program in Clinical Biochemistry, Hasanuddin University, J1. Perintis Kemerdekaan Km.10, Makassar, Indonesia \\ *Corresponding author. E-mail: anna.meiliana@prodia.co.id
}

\section{Abstract}

B ACKGROUND: Since the first umbilical cord blood (UCB) transplant, performed 25 years ago, UCB banks have been established worldwide for the collection and cryopreservation of UCB for autologous and allogeneic transplants.

CONTENT: Much has been learned in a relatively short time on the properties of UCB hematopoietic progenitors and their clinical application. More interestingly, non-hematopoietic stem cells have been isolated from UCB. These cells can be grown and differentiated into various tissues including bone, cartilage, liver, pancreas, nerve, muscle and so on. The non-hematopoietic stem cells have an advantage over other sources of stem cells, such as embryonic stem cells or induced pluripotent stem cells, because their supply is unlimited, they can be used in autologous or allogeneic situations, they need minimal manipulation and they raise no ethical concerns. Future studies will test the potential of UCB cells for the treatment of several diseases including, among other possibilities, diabetes, arthritis, burns, neurological disorder and myocardial infarction.

SUMMARY: In addition to hematopoietic stem cells, UCB contain a large number of non-hematopoietic stem cells. In the absence of ethical concern, the unlimited supply of UCB cells explains the increasing interest of using UCB for developing regenerative medicine.

KEYWORDS: UCB, transplantation, UCB bank, HSC, MSC, CD34, CD133, VSEL

\section{Abstrak}

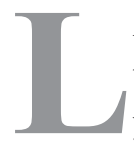

ATAR BELAKANG: Sejak transplantasi darah tali pusat (DTP) pertama yang dilakukan 25 tahun yang lalu, telah banyak didirikan bank DTP di seluruh dunia untuk menyimpan DTP, untuk dipakai pada transplantasi autologus maupun alogenik.

ISI: Banyak yang telah dipelajari dalam waktu yang relatif singkat tentang sifat progenitor hematopoietik DTP dan aplikasi klinisnya. Yang lebih menarik, sel punca non-hematopoietik telah diisolasi dari DTP. Sel ini dapat berkembang dan berdiferensiasi menjadi berbagai jaringan seperti tulang, tulang rawan, hati, pankreas, saraf, otot dan sebagainya. Sel punca non-hematopoietik ini memiliki kelebihan dibanding sel punca sumber lainnya seperti sel punca embrionik atau sel punca pluripoten hasil induksi, karena sumbernya tidak terbatas, dapat digunakan untuk situasi autologus maupun alogenik, membutuhkan manipulasi minimal dan tidak menimbulkan masalah etika. Penelitian di masa mendatang akan menguji potensi sel DTP untuk terapi berbagai penyakit, diantaranya adalah diabetes, artritis, luka bakar, gangguan saraf, dan infark miokard.

RINGKASAN: Selain sel punca hematopoietik, DTP mengandung banyak sel punca non-hematopoietik. Dengan tidak adanya masalah etika, ketersediaan sel DTP yang tidak terbatas ini meningkatkan keinginan dalam penggunaan DTP untuk pengembangan kedokteran regeneratif.

KATA KUNCI: DTP, transplantasi, bank DTP, HSC, MSC, CD34, CD133, VSEL

Indones Biomed J. 2014; 6(3): 115-22 


\section{Introduction}

The first umbilical cord blood (UCB) transplant (UCBT) by Gluckman et al. was performed in 1988 in a patient with Fanconi's anemia.(1) This patient had a healthy human leukocyte antigen (HLA)-identical sibling who was shown by prenatal testing to be unaffected by the disorder, to have a normal karyotype and to be HLA identical to the patient. Her cord blood was collected at birth, cryopreserved and used after thawing for transplantation. Since the first UCBT, more than 20,000 UCBTs have been reported worldwide and more than $620,000 \mathrm{UCB}$ units have been stored in more than 100 UCB banks.(2) The main practical advantages of using $\mathrm{UCB}$ as an alternative source of stem cells are the relative ease of procurement, the absence of risks for mothers and donors, the reduced likelihood of transmitting infections, particularly cytomegalovirus (CMV) and the ability to store fully tested and HLA-typed transplants in the frozen state, available for immediate use (3).

UCB bank (UCBB) established criteria for standardization of UCB collection, banking, processing and cryopreservation for unrelated donor transplants in patients with various hematological malignant and non-malignant diseases.(3) Recently, the use of UCB stem cells (UCB-SCs) in several regenerative medicine applications has expanded its clinical utility.

UCB-SCs contains a mixture of multipotent stem cells capable of giving rise to cells derived from the endodermal, mesodermal and ectodermal lineages. It has been shown that UCB-SCs have the ability to regenerate numerous tissue types, and when transplanted into animals and humans, have produced measurable functional improvements. $(4,5)$ Generally, tissue-derived stem cells have been described for neural (6), retinal (7), pancreas (8), skin (9) and liver tissues (10). UCB-SCs appear to be unique in their ability to undergo pluripotential differentiation. Thus, UCB-SCs appear to be a practical substitute for embryonic stem cells and are readily available for use in tissue engineering and regenerative medicine. Recently clinical trials have begun using UCB-SCs to treat type 1 diabetes mellitus (T1DM), cerebral palsy and peripheral vascular disease among others. $(4,5)$ UCB-SCs has transitioned from the laboratory to the clinic and numerous patients are currently being treated in clinical trials. Other trials will surely rapidly follow, including therapies for eyes, joints, wound and spinal cord. The key to these advances lies in the pluripotency of UCBSCs and their ability to be used in many instances under the practice of medicine, as it appears in many instances that it is possible to merely infuse the stem cells directly without timely and costly in vitro culture and differentiation.(11)

\section{UCB-SCs}

Hematopoietic stem cell (HSC) transplantation (HSCT) can be performed using stem cells derived from three sources: bone marrow (BM), peripheral blood (PB) and UCB. Only about $30 \%$ of patients in need of HSCT have a matchedrelated donor and, although there are currently around 10 million adult volunteer donors registered worldwide, still about $60 \%$ of patients will not find a suitably HLA-matched unrelated adult donor, and thus cannot access this potentially curative therapy.(12)

As UCB products are HLA-typed, tested for lack of infectious agents and stored, they are immediately available upon request and can be shipped to any transplant center in the world with relative ease and without delay. $(13,14)$ UCB has become such a popular adult stem cell source for many reasons, not least because over 130 million births worldwide per annum represents the largest, easily available stem cell source. It also allows for storage of units from ethnic minorities not easily possible within BM registries. (15) This potentially allows for an increase in the rate of matched unrelated donor allogeneic transplants.(16) It has also been found that there is a lower risk of graft versus host disease (GvHD) when transplanting UCB compared to BM.(17) This could be due to the fact that the cells transplanted from UCB are more naive and have lower HLA protein expression.(16) UCB has been shown to contain a higher frequency of early progenitor cells than PB or BM.(18) Further findings show that term and preterm UCB contain significantly higher number of early and committed progenitor cells, and that they are better able to form colony-forming-unit granulocyte-macrophage (CFUGM) when compared to adult PB.(19)

UCB also contains non-haematopoietic stem or progenitor cells including mesenchymal and endothelial precursor.(20) Even more recently UCB is becoming a real player in the regenerative medicine field. There are many groups looking to develop tissues for either transplantation or drug testing with many successes.(21) It has become a real alternative to $\mathrm{BM}$ and $\mathrm{PB}$ as a source of adult stem cells to treat multiple diseases. More than 85 conditions can currently be treated using this stem cell source, such as the previously mentioned Fanconi's anemia, a BM failure disorder (1), metabolic disorders like Krabbe's disease (22) and immune defects like severe combined immune deficiency (SCID) (23). Well over 1 million UCB have been 
stored globally in the last 10 years. Already, over 20,000 transplants been performed using UCB for haematopoietic reconstitution alone, now this potential is joined in the regenerative medicine.(21)

\section{UCBB}

$\mathrm{UCBB}$ has gained significant interest in recent years because of the success of UCBT and its more recent applications within regenerative medicine. Both public and private banking facilities have been established over the past 20 years to facilitate these endeavors.

Generally, UCB samples are red cell- and volumereduced prior to cryopreservation, in order to facilitate banking and minimize costs. Samples may be frozen using a variety of media, and can be stored in either cryovials or cryobags, generally in a limited number of frozen aliquots. The storage containers may also be overwrapped with a plastic protective sheath for protection from contact with the liquid nitrogen $\left(\mathrm{LN}_{2}\right)$ itself, as well as a barrier to sample contamination.(24) Two of the most critical steps in the banking process are the cryopreservation and long-term $\mathrm{LN}_{2}$ storage of the sample in such a fashion that the sample will be viable and usable decades into the future.(24)

Finally, great concern was raised in the mid-1990s over potential cross-sample contamination during liquidphase $\mathrm{LN}_{2}$ storage, after the demonstration that pathogenic viruses and other microbial pathogens could survive longterm direct contact with $\mathrm{LN}_{2}$ and could infect other samples stored in the same dewar. $(25,26)$

While donor-specific factors probably impact on the potency of a UCB unit (27), the collection, processing, distribution and infusion stages may also affect the potency of this stem cell product, whatever processing technology a laboratory chooses, the goal is to achieve maximal recovery of total nucleated cells (TNC), mononuclear cells (MNCs), CD $34^{+}$cells, CFU, progenitor cells and stem cells.(28) While the overall cellular recovery declines as a result of the freezing process, the overall potency may be preserved for more than 15 years if the UCB is maintained below $-150^{\circ} \mathrm{C}$. (29)

Currently the United States Food and Drug Administration (US FDA) recommends evaluation of potency through assessment of the following in vitro assays: TNC count, cell viability and CD34 analysis. TNC are measured using automated hematology analyzers, the CD34 assay is performed using flow cytometry, and the CFU assay is accomplished using a methylcellulose-based media impregnated with cytokines.(28) There is increasing evidence that UCB unit potency should be assessed postcryopreservation because events associated with freezing and storage can affect subsequent cellular viability and overall UCB potency.(28)

Although there are many benefits to using UCB for transplantation there is one major limitation: the TNC count and cell number recoverable from a single unit. This is affected by unit size, maternal factors such as number of previous pregnancies and age of mother (30), limited volumes available from each sample, but not least the processing method used. Together, these factors highlight the need to make processing as efficient as possible (31) to make UCBB a real option. Many methods are currently available. Techniques were varied; from density gradient separation, like Lymphoprep or Ficoll-Paque (32), rouleaux formation using Hetastarch (HES), a starch based method causing red cells to clump (33), plasma depletion; a simple volume reduction method which avoids the addition of any chemicals and simply removes the plasma (34), a novel closed separation kit, known as PrepaCyte-CB which offers rapid and specific cell separation (35), and the only fully automated system, provided by Biosafe, known as the 'Sepax' machine (36). PrepaCyte-CB and an automated centrifugal machine, Sepax gives the highest recovery of nucleated cells, an average of 78.8\% ( $\mathrm{SD} \pm 21.36)$.(21)

Fifteen to $24 \%$ of patients receiving UCBT do not engraft. One potential cause of engraftment failure is a loss of reconstituting HSC potency that may have occurred at some stage during UCB collection, processing, storage, shipment and infusion.(28) The National Marrow Donor Program (NMDP) Cord Blood Advisory Group can assist in the development of assays by providing resources in terms of UCB, expertise and access to a network for testing assays, once developed, in the field.(28)

\section{UCB-SCs for Hematopoietic Disorders}

HSC transplantation is a curative approach for a variety of malignant and non-malignant diseases.(37-40) Mobilized PB, BM and UCB are the main sources of HSC. UCB from related and unrelated donors has emerged as a promising source of stem cells for a variety of hematological disorders and as a supportive therapy for malignant diseases.(41-44) In addition to its widespread availability, UCB contains HSCs and hematopoietic progenitor cells (HPCs) with higher immunological tolerance and higher proliferation ability than adult-derived BM (44), however, the low yield of HSCs and HPCs in UCB grafts limits their applications in clinics. (45) For optimum engraftment, current transplantation 
requires at least $2,500,000 \mathrm{CD}^{+} 4^{+}$cells per kilogram of patient body weight.(46) An optimally collected UCB donation generates approximately $10,000,000 \mathrm{CD}^{+} 4^{+}$cells, which is just adequate for pediatric patients right now.(47)

UCB HSCs have numerous phenotypic and functional characteristics that distinguish them from their adult

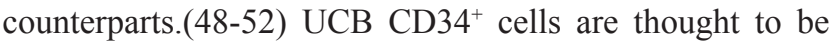
more primitive due to their extensive proliferative capacity, their increased ability to generate hematopoietic colonies in vitro, their capacity to produce erythroid cells, which contain fetal hemoglobins, and the ability of smaller numbers of such cells to reconstitute a myeloablated allogeneic recipient. $(48,53)$

While UCB represents a readily available source of HSC for transplantation, the low cell dose available in a UCB graft correlates with a significant delay in hematopoietic recovery and a higher risk of primary graft failure. $(54,55)$ In order to provide higher absolute numbers of HSC for infusion, significant efforts have focused on developing clinically relevant ex vivo expansion methodologies, many of which require an initial enrichment of the progenitor population.(56-60)

For over a decade, CD34 was the gold standard identification selection marker for early HSPC. Recently, cells expressing CD133 antigen were considered to be a potent substitute for $\mathrm{CD} 34^{+}$cells. Phenotypic and functional studies revealed $\mathrm{UCB} \mathrm{CD} 133^{+}$populations contain higher levels of early HSPC than UCB CD $34^{+}$harvested populations.(61,62) CD133 was initially considered a surface molecule expressed by more primitive HSC and endothelial precursor cells expressing vascular endothelial growth factor receptor (VEGF-R).(63) Advances in various fields have implicated $\mathrm{CD}_{133^{+}}$cells, which, apart from hematopoietic diseases, have also been involved as therapy for neurologic and myocardial diseases as well as in other research applications.(64) A subpopulation of $\mathrm{CD}^{+}$ $\mathrm{CD}_{133^{+}}$cells has been described in UCB and identified as more primitive than $\mathrm{CD} 4^{+}$cells (65).

A number of devices and reagents are commercially available for enrichment of $\mathrm{CD} 34^{+}$or $\mathrm{CD} 133^{+}$populations; however, these devices must comply with current good manufacturing practices (cGMP) if they are to be used in the manufacturing process of cellular therapies.(66) The CliniMACS Cell Separation System from Miltenyi Biotec is currently the only cGMP-grade cell separation system available for immunomagnetic separation of CD34 progenitor cells from blood products.(67) CD $34^{+}$enrichment from UCB units is used increasingly in clinical applications involving ex vivo expansion.(67)

\section{UCB-SCs for Non-Hematological Disorders}

UCB-SCs are capable of giving rise to hematopoietic, epithelial, endothelial and neural tissues both in vitro and in vivo. Thus, UCB-SCs are amenable to treat a wide variety of diseases including cardiovascular, ophthalmic, orthopaedic, neurological and endocrine diseases.(11) Autologous UCBSCs transfusion in children with T1DM is safe but has yet to demonstrate efficacy in preserving C-peptide. Larger randomized studies as well as 2 years post-infusion followup of this cohort are needed to determine whether autologous UCB-based approaches can be used to slow the decline of endogenous insulin production in children with T1DM.(68)

Peripheral arterial disease (PAD) is the most important manifestation of systemic atherosclerosis interesting lower extremities. The end stage of PAD is critical limb ischemia (CLI), whose peculiar symptom is rest pain refractory to analgesics lasting more than 2 weeks with or without ischemic lesions. The use of autologous stem and progenitor cells in cell therapy is limited by their rarity in adult PB. In addition, progenitor cells in PAD patients may be functionally altered (69). Conversely, UCB contains a higher number of progenitor cells, more functional and efficient than those in $\mathrm{PB}$, able to induce the formation of stable vascular structures inside the ischemic tissues.(70)

Several innovative therapies with human UCBSCs (hUCB-SCs) are currently developing to treat central nervous system (CNS) diseases. It has been shown that UCB contains multipotent lineage-negative (LinNEG) SCs capable of neuronal differentiation. Clinically useful UCB samples are stored in different biobanks worldwide, but the content and neurogenic properties of LinNEG cells are unknown. Jurga et al. showed that Sepax-processed blood units contained 10-fold higher number of LinNEG cells after cryopreservation in comparison to all other methods. (71)

Neonatal hypoxic ischemic (HI) encephalopathy due to perinatal asphyxia is an important cause of death in the neonatal period, in both developing and developed countries.(72) Among the surviving infants, up to $25 \%$ will have a permanent neurologic deficit in the form of cerebral palsy, epilepsy, learning disability, or mental retardation. (73) Treatment is currently limited to supportive intensive care. Given the severity of the problem, it is necessary to find new approaches that could reduce the neurologic sequelae of HI newborns (74).

In the last few years, preclinical studies have shown that UCB-SCs injected systemically in the acute phase of animal models of stroke, have a therapeutic effect. These 
cells can reduce the area of brain infarction (75) and the inflammation, and increase the regenerative capacity of the brain, improving behavioral recovery (76). The potential of UCB-SCs to reduce the neurologic deficits associated with neonatal hypoxia-ischemia was shown in rats in a study that assessed the functional benefits of these cells, using a walking-pattern analysis test. The UCB-SCs, when injected intraperitoneally 24 hours after the insult, migrated to areas of brain damage in large numbers, and alleviated the spastic paresis of the animals.(77) Thus, UCB-SCs transplantation might rescue striatal neurons from cell death after a neonatal $\mathrm{HI}$ injury resulting in better functional recovery.(74)

Cerebral palsy (CP) is the most frequent neurological disorder associated with perinatal injury of the developing brain. Major brain lesions associated with $\mathrm{CP}$ are white matter damage (WMD) in preterm infants and corticosubcortical lesions in term newborns. Cell therapy is considered promising for the repair of brain damage. The hUCB-MNCs are a rich source of various stem cells that could be of interest in repairing perinatal brain damage (78).

Spinal cord injury (SCI) is often characterized by immediate and irreversible loss of sensory and motor function below the level of injury. Cell transplantation is a potential method for certain neurological diseases as well as a viable treatment for acute SCI.(79-83) The present results indicated CD34 $4^{+}$UCB-SCs accelerated function recovery after SCI by governing blood vessel formation and restoration. Also, early administration of $\mathrm{CD} 34^{+} \mathrm{UCB}-$ SCs was able to increase tissue vitality and the blood vessel density, as well as improve behavioral deficits after SCI obviously.(84)

Traumatic brain injury (TBI) is a major public health problem associated with death and permanent disability worldwide.(85) Both acute and chronic symptoms accompany TBI, with survivors suffering from progressive post-TBI pathological manifestations such as neuroinflammation coupled with behavioral dysfunctions including sensory motor deficits, learning and memory impairments and a range of neuropsychiatric symptoms including anxiety, depression and aggression. $(86,87)$ At present, there is significant unmet need for clinically efficacious therapies for TBI.(88)

A number of groups have focused on the potential of UCB-SCs as a graft source for various intractable neurological disorders (e.g., stroke, Parkinson's disease and Huntington's disease, among others).(89) Moreover, clinical trials have been performed to determine the efficacy of UCB-SCs in cerebral palsy, inborn metabolic disorders and stroke. (90) Combined therapy of UCB-SCs plus granulocyte colony stimulating factor (GCSF) synergistically dampened traumatic brain injury-induced neuroinflammation while significantly enhancing endogenous neurogenesis and reducing hippocampal cell loss.(91)

UCB-SCs holds great potential as a source for cellular therapy. Mesenchymal stromal cells (MSC) and unrestricted somatic stem cells (USSC) found in UCB have been reported to differentiate in vivo into osteoblasts, adipocytes and neural progenitor cells (92). UCB-SCs cells have been used in high doses to delay symptom progression in a mouse model of amyotrophic lateral sclerosis (ALS) (93) and have been identified within the central nervous system of a patient with Krabbe's disease 10 months post-UCBSC transplant (94), suggesting the persistence of these cells as a possible contributor to cellular repair in patients with neurodegenerative diseases (95). UCB-MSC could restore behavioral functions and attenuate the histopathological deficits of experimental autoimmune encephalomyelitis mice over the long term (i.e., 50 days) by suppression of perivascular immune cell infiltrations and reduction in both demyelination and axonal injury in the spinal cord. These findings suggest that transplantation of UCB-MSCs may be a potential therapy.(96)

\section{UCB-SCs Successes}

SC Researchers at the Steenblock Research Institute in San Clemente, California, have been following the cases of patients treated with UCB-SCs, as well as tabulating results from pilot studies performed abroad involving stem cell therapy for specific conditions such as cerebral palsy in children and MS in adults. The following are but a few of the many responses documented as of the date of publications.(97)

A 65 years old man with progressive multiple sclerosis (MS) was treated with UCB-SCs in July 2003. Prior to this treatment, he could not swallow water normally. Within a week of receiving UCB-SCs, he was able to do so without a problem. He subsequently made noticeable gains in his ability to get around and could communicate more clearly. (97)

Ramirez hUCB-SCs therapy program in Mexico has treated more than forty children with cerebral palsy since March 2003. Eighty five percent of these children have experienced significant improvements in motor skills and cognitive functions. In one case, a four years old boy was cortically blind (a lack of visual functioning despite structurally intact eyes), could not speak well, and could not get around well prior to therapy with UCB-SCs. Within seven months of therapy, however, he was able to track 
objects with his eyes, was beginning to speak, and could move around more ably.(97)

Jordan Logan, a four years old girl, with a terminal genetically based neurological disease called metachromatic leukodystrophy (MLD) was treated with 1.5 million UCBSCs. MLD is caused partly by a genetic defect in which a gene critical to the production of an enzyme called arylsulfatase A (ARS-A) is missing or not functioning properly. This enzyme makes it possible for a person's body to deal with toxic molecule that we all generate called sulfatides children and adults who do not produce ARS-A or very little experience declines in their neurological function that culminate in disability and death. Within two months of her UCB-SCs injection, however, she could track objects with her eyes and lift her arms and legs high in the air. Eventually, two of the three medications she was on were discontinued. Jordan's story has appeared in numerous regional and national newspapers, and also has been the focus of TV coverage in Missisippi.(97)

\section{Conclusion}

In the last few years, pure UCB-SCs have been utilized by physicians to treat a multitude of intractable diseases such as progressive MS, ALS, macular degeneration, retinitis pigmentosa, stroke, diabetes, and various forms of heart disease. This body of patient responses indicates that UCB-SCs therapy does produce clinically significant improvements in many instances. While certainly no cure for all, UCB-SC therapy appears to be amassing a respectable track record in terms of both safety and clinical utility.

\section{References}

1. Gluckman E, Broxmeyer HA, Auerbach AD, Friedman HS, Douglas GW, Devergie A, et al. Hematopoietic reconstitution in a patient with Fanconi 's anemia by means of umbilical cord blood from an HLA-identical sibling. New Engl J Med 1989; 321: 1174-8.

2. Bone Marrow Donors Worldwide. Total number of cord blood units. Leiden, The Netherlands. Cited 2015 Jan 7. Available from: https:// www.bmdw.org/index.php?id=statistics_cordblood.

3. Gluckman E. History of cord blood transplantation. Bone Marrow Transplant 2009; 44: 621-6.

4. Harris DT, Rogers I. Umbilical cord blood: a unique source of pluripotent stem cells for regenerative medicine. Curr Stem Cell Res Ther. 2007; 2: 301-9.

5. Harris DT, He X, Badowski M, Nichols JC. Regenerative medicine of the eye: a short review. In: Levicar N, Habib NA, Dimarakis I, Gordon MY, editors. Stem Cell Repair \& Regeneration, Vol. 3. London: Imperial College Press; 2008. p.211-25.

6. Seaberg RM, van der Kooy D. Adult rodent neurogenic regions: the ventricular subependyma contains neural stem cells, but the dentate gyrus contains restricted progenitors. J Neurosci. 2002; 22: 1784-
93.

7. Tropepe V, Coles BL, Chiasson BJ, Horsford DJ, Elia AJ, McInnes $\mathrm{RR}$, et al. Retinal stem cells in the adult mammalian eye. Science 2000; 287: 2032-6.

8. Seaberg RM, Smukler SR, Kieffer TJ, Enikolopov G, Asghar Z, Wheeler MB, et al. Clonal identification of multipotent precursors from adult mouse pancreas that generate neural and pancreatic lineages. Nat Biotechnol. 2004; 22: 1115-24.

9. Toma JG, Akhavan M, Fernandes KJ, Barnabé-Heider F, Sadikot A, Kaplan DR, et al. Isolation of multipotent adult stem cells from the dermis of mammalian skin. Nat Cell Biol. 2001; 3: 778-84.

10. Yoon BI, Choi YK, Kim DY. Differentiation processes of oval cells into hepatocytes: proposals based on morphological and phenotypical traits in carcinogen-treated hamster liver. Journal of Comparative Pathology 2004; 131: 1-9.

11. Harris DT. Non-haematological uses of cord blood stem cells. Br J Haematol. 2009; 147: 177-84.

12. Wagner J, Laughlin M, Petz L. Summary of the 7th Annual International Cord Blood Transplantation Symposium. Biol Blood Marrow Transplant. 2010; 16: 12-27.

13. Barker JN, Krepski TP, DeFor TE, Davies SM, Wagner JE, Weisdorf DJ. Searching for unrelated donor hematopoietic stem cells: availability and speed of umbilical cord blood versus bone marrow. Biol Blood Marrow Transplant. 2002; 8:257-60.

14. Chow R, Lin E, Tonai R, Bolanos R, Connor C, Mendoza A. Cell recovery comparison between plasma depletion/reduction- and red cell reduction-processing of umbilical cord blood. Cytotherapy. 2011; 13: 1105-19.

15. Davey S, Armitage S, Rocha V, Garnier F, Brown J, Brown CJ, et al. The London Cord Blood Bank: analysis of banking and transplantation outcome. Br J Haematol. 2004; 125: 358-65

16. Fasouliotis SJ, Schenker JG. Human umbilical cord blood banking and transplantation: a state of the art. Eur J Obstet Gynecol Reprod Biol. 2000; 90: 13-25

17. Grewal SS, Barker JN, Davies SM, Wagner JE. Unrelated donor hematopoietic cell transplantation: marrow or umbilical cord blood? Blood. 2003; 101: 4233-44.

18. Kekarainen T, Mannelin S, Laine J, Jaatinen T. Optimization of immunomagnetic separation for cord blood-derived hematopoietic stem cells. BMC Cell Biol. 2006; 7: 30

19. Broxmeyer HE, Gluckman E, Auerbach A, Douglas GW, Friedman $\mathrm{H}$, Cooper $\mathrm{S}$, et al. Human umbilical cord blood: a clinically useful source of transplantable hematopoietic stem/progenitor cells. Int J Cell Cloning. 1990; 8 Suppl 1:76-89.

20. Tondreau T, Meuleman N, Delforge A, Dejeneffe M, Leroy R, Massy $\mathrm{M}$, et al. Mesenchymal stem cells derived from CD133-positive cells in mobilized peripheral blood and cord blood: proliferation, Oct4 expression, and plasticity. Stem Cells. 2005; 23: 1105-12.

21. Basford C, Forraz N, Habibollah S, Hanger K, McGuckin C. The Cord Blood Separation League Table: a Comparison of the Major Clinical Grade Harvesting Techniques for Cord Blood Stem Cells. Int J Stem Cells. 2010; 3: 32-45.

22. Escolar ML, Poe MD, Provenzale JM, Richards KC, Allison J, Wood $\mathrm{S}$, et al. Transplantation of umbilical cord blood in babies with infantile Krabbe's disease. N Engl J Med. 2005; 352: 2069-81,

23. Slatter MA, Gennery AR. Umbilical cord stem cell transplantation for primary immunodeficiencies. Expert Opin Biol Ther. 2006; 6: 55565.

24. Harris DT. Optimizing cord blood sample cryopreservation. Cytotherapy. 2012; 14: 359-65.

25. Tedder RS, Zuckerman MA, Brink NS, Goldstone AH, Fielding A, Blair S, et al. Hepatitis B transmission from contaminated cryopreservation tank. Lancet. 1995; 346: 137-40.

26. Fountain D, Ralston M, Higins N, Gorlin JB, Uhl L, Wheeler C, et al. Liquid nitrogen freezers: a potential source of microbial 
contamination of hematopoietic stem cell components. Transfusion. 1997; 37: 585-91.

27. Cairo MS, Wagner EL, Fraser J, Cohen G, van de Ven C, Carter SL, et al. Characterization of banked umbilical cord blood hematopoietic progenitor cells and lymphocyte subsets and correlation with ethnicity, birth weight, sex, and type of delivery: a Cord Blood Transplantation (COBLT) study report. Transfusion. 2005; 45: 85666.

28. Spellman S, Hurley CK, Brady C, Phillips-Johnson L, Chow R, Laughlin $\mathrm{M}$, et al. Guidelines for the development and validation of new potency assays for the evaluation of umbilical cord blood. Cytotherapy 2011; 13: 848-55.

29. Broxmeyer HE, Srour EF, Hangoc G, Cooper S, Anderson SA, Bodine DM. High-efficiency recovery of functional hematopoietic progenitor and stem cells from human cord blood cryopreserved for 15 years. Proc Natl Acad Sci USA. 2003; 100: 645-50.

30. McGuckin CP, Basford C, Hanger K, Habibollah S, Forraz N. Cord blood revelations: the importance of being a first born girl, big, on time and to a young mother! Early Hum Dev. 2007;83: 733-41.

31. Rubinstein P, Dobrila L, Rosenfield RE, Adamson JW, Migliaccio G, Migliaccio AR, et al. Processing and cryopreservation of placental/ umbilical cord blood for unrelated bone marrow reconstitution. Proc Natl Acad Sci USA 1995; 92: 10119-22.

32. Vannier JP, Monconduit M, Piguet H. Comparison between 2 density gradients for separation of CFU. Biomedicine 1980; 33: 236-9.

33. Solves P, Mirabet V, Planelles D, Blasco I, Perales A, CarbonellUberos F, et al. Red blood cell depletion with a semiautomated system or hydroxyethyl starch sedimentation for routine cord blood banking: a comparative study. Transfusion. 2005; 45: 867-73.

34. Chow R, Nademanee A, Rosenthal J, Karanes C, Jaing TH, Graham $\mathrm{ML}$, et al. Analysis of hematopoietic cell transplants using plasmadepleted cord blood products that are not red blood cell reduced. Biol Blood Marrow Transplant. 2007; 13: 1346-57.

35. Ademokun JA, Chapman C, Dunn J, Lander D, Mair K, Proctor $\mathrm{SJ}$, et al. Umbilical cord blood collection and separation for haematopoietic progenitor cell banking. Bone Marrow Transplant. 1997; 19: 1023-8.

36. Lapierre V, Pellegrini N, Bardey I, Malugani C, Saas P, Garnache $\mathrm{F}$, et al. Cord blood volume reduction using an automated system (Sepax) vs. a semi-automated system (Optipress II) and a manual method (hydroxyethyl starch sedimentation) for routine cord blood banking: a comparative study. Cytotherapy. 2007; 9: 165-9.

37. Rowe JM. Optimal management of adults with ALL. Br J Haematol. 2009; 144: 468-83.

38. Koreth J, Schlenk R, Kopecky KJ, Honda S, Sierra J, Djulbegovic $\mathrm{BJ}$, et al. Allogeneic stem cell transplantation for acute myeloid leukemia in first complete remission: system- atic review and metaanalysis of prospective clinical trials. J Am Med Assoc. 2009; 30: 2349-61.

39. Bosticardo M, Marangoni F, Aiuti A, Villa A, Grazia Roncarolo M. Recent advances in understanding the pathophysiology of WiskottAldrich syndrome. Blood. 2009;113:6288-95.

40. Filipovich A. Hematopoietic cell transplantation for correction of primary immunodeficiencies. Bone Marrow Transplant. 2008; 42(Suppl 1): S49-52.

41. Laughlin MJ, Barker J, Bambach B, Koc ON, Rizzieri DA, Wagner $\mathrm{JE}$, et al. Hematopoietic engraftment and survival in adult recipients of umbilical-cord blood from unrelated donors. N Engl J Med. 2001; 344: 1815-22.

42. Rubinstein P, Carrier C, Scaradavou A, Kurtzberg J, Adamson J, Migliaccio AR, et al. Outcomes among 562 recipients of placentalblood transplants from unrelated donors. N Engl J Med. 1998; 339: 1565-77.

43. Kurtzberg J, Laughlin M, Graham ML, Smith C, Olson JF, Halperin EC, et al. Placental blood as a source of hematopoietic stem cells for transplantation into unrelated recipients. N Engl J Med. 1996; 335: 157-66.

44. Gluckman E, Rocha V, Boyer-Chammard A, Locatelli F, Arcese W, Pasquini R, et al. Outcome of cord-blood transplantation from related and unrelated donors. Eurocord Transplant Group and the European Blood and Marrow Transplantation Group. N Engl J Med. 1997; 337: 373-81.

45. Paulin T. Importance of bone marrow cell dose in bone marrow transplantation. Clin Transplant. 1992; 6: 48-54.

46. Rocha V, Wagner JE Jr, Sobocinski KA, Klein JP, Zhang MJ, Horowitz MM, et al. Graft-versus-host disease in children who have received a cord-blood or bone marrow transplant from an HLA-identical sibling. Eurocord and International Bone Marrow Transplant Registry Working Committee on Alternative Donor and Stem Cell Sources. N Engl J Med. 2000; 342: 1846-54.

47. Zhang Y, Chai C, Jiang XS, Teoh SH, Leong KW. Co-culture of umbilical cord blood CD34 ${ }^{+}$cells with human mesenchymal stem cells. Tissue Eng. 2006; 12: 2161-70.

48. Cairo MS, Wagner JE. Placental and/or umbilical cord blood: an alternative source of hematopoietic stem cells for transplantation. Blood. 1997; 90: 4665-78.

49. Dahlberg A, Delaney C, Bernstein ID. Ex vivo expansion of human hematopoietic stem and progenitor cells. Blood. 2011; 117: 608390 .

50. Delaney C, Bollard CM, Shpall EJ. Cord blood graft engineering. Biol Blood Marrow Transplant. 2013; 19 (1 suppl): S74-8.

51. Navarrete C, Contreras M. Cord blood banking: a historical perspective. Br J Haematol. 2009; 147: 236-45.

52. Stanevsky A, Goldstein G, Nagler A. Umbilical cord blood transplantation: pros, cons and beyond. Blood Rev. 2009; 23: 199204.

53. Chaurasia P, Gajzer DC, Schaniel C, D’Souza S, Hoffman R. Epigenetic reprogramming induces the expansion of cord blood stem cells. J Clin Invest. 2014; 124: 2378-95.

54. Brunstein CG, Gutman JA, Weisdorf DJ, Woolfrey AE, Defor TE, Gooley TA, et al. Allogeneic hematopoietic cell transplantation for hematologic malignancy: relative risks and benefits of double umbilical cord blood. Blood. 2010; 116: 4693-9.

55. Delaney C, Ratajczak MZ, Laughlin MJ. Strategies to enhance umbilical cord blood stem cell engraftment in adult patients. Expert Rev Hematol. 2010; 3: 273-83.

56. Delaney C, Heimfeld S, Brashem-Stein C, Voorhies H, Manger RL, Bernstein ID. Notch-mediated expansion of human cord blood progenitor cells capable of rapid myeloid reconstitution. Nat Med. 2010; 16: 232-6.

57. Gunetti M, Ferrero I, Rustichelli D, Berger M, Gammaitoni L, Timeus $\mathrm{F}$, et al. Refreezing of cord blood hematopoietic stem cells for allogenic transplantation: in vitro and in vivo validation of a clinical phase I/II protocol in European and Italian Good Manufacturing Practice conditions. Exp Hematol. 2008; 36: 235-43.

58. Ko KH, Nordon R, O’Brien TA, Symonds G, Dolnikov A. Ex vivo expansion of haematopoietic stem cells to improve engraftment in stem cell transplantation. Methods Mol Biol. 2011; 761: 249-60.

59. Madlambayan GJ, Rogers I, Purpura KA, Ito C, Yu M, Kirouac D, et al. Clinically relevant expansion of hematopoietic stem cells with conserved function in a single-use, closed-system bioprocess. Biol Blood Marrow Transplant. 2006; 12: 1020-30.

60. Robinson SN, Ng J, Niu T, Yang H, McMannis JD, Karandish S, et al. Superior ex vivo cord blood expansion following co-culture with bone marrow-derived mesenchymal stem cells. Bone Marrow Transplant. 2006; 37: 359-66.

61. Pasino M, Lanza T, Marotta F, Scarso L, De Biasio P, Amato S, et $a l$. Flow cytometric and functional characterization of $\mathrm{AC} 133^{+}$cells from human umbilical cord blood. Br J Haematol. 2000; 108: 793800 . 
62. Forraz N, Pettengell R, Deglesne PA, McGuckin CP. AC133 umbilical cord blood progenitors demonstrate rapid self-renewal and low apoptosis. Br J Haematol. 2002; 119: 516-24.

63. Pelagiadis I, Relakis K, Kalmanti L, Dimitriou H. CD133 immunomagnetic separation: effectiveness of the method for CD133(+) isolation from umbilical cord blood. Cytotherapy. 2012; 14: 701-6.

64. Meregalli M, Farini A, Belicchi M,TorrenteY. CD133(+) cells isolated from various sources and their role in future clinical perspectives. Expert Opin Biol Ther. 2010; 10: 1521-8.

65. Gallacher L, Murdoch B, Wu DM, Karanu FN, Keeney M, Bhatia M. Isolation and characterization of human CD34(-) Lin(-) and CD34(+) Lin(-) hematopoietic stem cells using cell surface markers AC133 and CD7. Blood. 2000; 95: 2813-20.

66. U.S. Food and Drug Administration [homepage on the internet]. Silverspring: CFR - Code of Federal Regulations Title 21; 2014 [updated 2015 Jan 8; cited 2015 Jan 9]. Available from: http:// www.accessdata.fda.gov/scripts/cdrh/cfdocs/cfcfr/CFRSearch. cfm?CFRPart=211.

67. Blake JM, Nicoud IB, Weber D, Voorhies H, Guthrie KA, Heimfeld $\mathrm{S}$, et al. Improved immunomagnetic enrichment of CD34(+) cells from umbilical cord blood using the CliniMACS cell separation system. Cytotherapy. 2012; 14: 818-22.

68. Haller MJ, Wasserfall CH, Hulme MA, Cintron M, Brusko TM, McGrail KM, et al. Autologous umbilical cord blood transfusion in young children with type 1 diabetes fails to preserve C-peptide. Diabetes Care. 2011; 34: 2567-9.

69. Morishita T, Uzui H, Nakano A, Mitsuke Y, Geshi T, Ueda T, et al. Number of endothelial progenitor cells in peripheral artery disease as a marker of severity and association with pentraxin-3, malondialdehyde-modified low-density lipoprotein and membrane type-1 matrix metalloproteinase. J Atheroscler Thromb. 2012; 19: 149-58.

70. Perotti C, Arici V, Cervio M, Del Fante C, Calliada F, Gnecchi M, et al. Allogeneic lethally irradiated cord blood mononuclear cells in no-option critical limb ischemia: a "box of rain". Stem Cells Dev. 2013; 22: 2806-12.

71. Jurga M, Forraz N, Basford C, Atzeni G, Trevelyan AJ, Habibollah S, et al. Neurogenic properties and a clinical relevance of multipotent stem cells derived from cord blood samples stored in the biobanks. Stem Cells Dev. 2012; 21: 923-36.

72. Lawn JE, Cousens S, Zupan J. 4 million neonatal deaths: When? Where? Why? Lancet. 2005; 365: 891-900.

73. Vannucci RC, Connor JR, Mauger DT, Palmer C, Smith MB, Towfighi $\mathrm{J}$, et al. Rat model of perinatal hypoxic-ischemic brain damage. $\mathrm{J}$ Neurosci Res. 1999; 55: 158-63.

74. Pimentel-Coelho PM, Magalhaes ES, Lopes LM, deAzevedo LC, Santiago MF, Mendez-Otero R. Human Cord Blood Transplantation in a Neonatal Rat Model of Hypoxic-Ischemic Brain Damage: Functional Outcome Related to Neuroprotection in the Striatum. Stem Cell Dev. 2010; 19: 351-6.

75. Vendrame M, Cassady J, Newcomb J, Butler T, Pennypacker KR, Zigova $\mathrm{T}$, et al. Infusion of human umbilical cord blood cells in a rat model of stroke dose-dependently rescues behavioral deficits and reduces infarct volume. Stroke. 2004; 35: 2390-5.

76. Chen J, Sanberg PR, Li Y, Wang L, Lu M, Willing AE, et al. Intravenous administration of human umbilical cord blood reduces behavioral deficits after stroke in rats. Stroke. 2001; 32: 2682-8.

77. Meier C, Middelanis J, Wasielewski B, Neuhoff S, Roth-Haerer A, Gantert M, et al. Spastic paresis after perinatal brain damage in rats is reduced by human cord blood mononuclear cells. Pediatr Res. 2006; 59: 244-9.

78. Dalous J, Pansiot J, Pham H, Chatel P, Nadaraja C, D'Agostino ID. Use of Human Umbilical Cord Blood Mononuclear Cells to Prevent
Perinatal Brain Injury: A Preclinical Study. Stem Cells Dev. 2013; 22: 169-79.

79. Sobani ZA, Quadri SA, Enam SA. Stem cells for spinal cord regeneration: current status. Surg Neurol Int. 2010; 1: 93. doi: 10.4103/2152-7806.74240.

80. Garbossa D, Boido M, Fontanella M, Fronda C, Ducati A, Vercelli A. Recent therapeutic strategies for spinal cord injury treatment: possible role of stem cells. Neurosurg Rev. 2012; 35: 293-311.

81. Gurudutta GU, Satija NK, Singh VK, Verma YK, Gupta P, Tripathi RP. Stem cell therapy: a novel \& futuristic treatment modality for disaster injuries. Indian J Med Res. 2012; 135: 15-25.

82. Ruff CA, Wilcox JT, Fehlings MG. Cell-based transplantation strategies to promote plasticity following spinal cord injury. Exp Neurol. 2012; 235: 78-90.

83. Sandner B, Prang P, Rivera FJ, Aigner L, Blesch A, Weidner N. Neural stem cells for spinal cord repair. Cell Tissue Res. 2012; 349: 349-62.

84. Ning G, Tang L, Wu Q, Li Y, Li Y, Zhang C, et al. Human umbilical cord blood stem cells for spinal cord injury: early transplantation results in better local angiogenesis. Regen Med. 2013; 8: 271-81.

85. Faul M, Xu L, Wald MM, Coronado VG. Traumatic Brain Injury in the United States: Emergency Department Visits, Hospitalizations and Deaths 2002-2006. Atlanta: Centers for Disease Control and Prevention, National Center for Injury Prevention and Control; 2010.

86. Azouvi P, Vallat-Azouvi C, Belmont A. Cognitive deficits after traumatic coma. Prog Brain Res. 2009; 177: 89-110.

87. Wong D, Dahm J, Ponsford J. Factor structure of the depression anxiety stress scales in individuals with traumatic brain injury. Brain Inj. 2013; 27: 1377-82.

88. Kaneko Y, Tajiri N, Yu S, Hayashi T, Stahl CE, Bae E, et al. Nestin overexpression precedes caspase-3 upregulation in rats exposed to controlled cortical impact traumatic brain injury. Cell Med. 2012; 4: 55-63.

89. Sanberg PR, Eve DJ, Metcalf Borlongan CV. Advantages and challenges of alternative sources of adult-derived stem cells for brain repair in stroke. Prog. Brain Res. 2012; 201: 99-117.

90. Ilic D, Miere C, Lazic E. Umbilical cord blood cells: clinical trials in non-hematological disorders. Br Med Bull. 2012; 102: 43-57.

91. de la pena I, Sanberg PR, Acosta S, Lin SZ, Borlongan CV. Umbilical cord blood cell and granulocyte-colony stimulating factor: combination therapy for traumatic brain injury. Regen Med. 2014; 9: 409-12.

92. Garbuzova-Davis S, Sanberg CD, Kuzmin-Nichols N, Willing AE, Gemma C, Bickford PC, et al. Human umbilical cord blood treatment in a mouse model of ALS: optimization of cell dose. PLoS ONE. 2008; 3: e2494. doi: 10.1371/journal.pone.0002494.

93. Kurtzberg J, Kosaras B, Stephens C, Snyder EY. Umbilical cord blood cells engraft and differentiate into neural tissue after human transplantation. Biol Blood Marrow Transplant. 2003; 9: 128.

94. Goldman SA, Schanz S, Windrem MS. Stem cell-based strategies for treating pediatric disorders of myelin. Hum Mol Genet. 2008; 17: R76-83. doi: http://dx.doi.org/10.1016/S1083-8791(03)80211-2.

95. Tracy ET, Zhang CY, Gentry T, Shoulars KV, Kurtzberg J. Isolation and expansion of oligodendrocyte progenitor cells from cryopreserved human umbilical cord blood. Cytotherapy 2011; 13: 722-9.

96. Liu R, Zhang Z, Lu Z, Borlongan C, Pan J, Chen J, et al. Human Umbilical Cord Stem Cells Ameliorate Experimental Autoimmune Encephalomyelitis by Regulating Immunoinflammation and Remyelination. Stem Cells Dev. 2013; 22: 1053-62.

97. Steenblock D, Payne AG. Umbilical Cord Stem Cell Therapy: The Gift of Healing from Healthy Newborns. Chapter 2. Basic Health Publication; 2006. 